\title{
Evaluation of some unconventional plant proteins in diets for Red Tilapia (Oreochromis spp) fingerlings.
}

\author{
G.D.I.Hassanen ${ }^{a}$, A.Y.EL-Daker ${ }^{\text {b }}$, I.P. Saoud ${ }^{\text {c }}$, GH.A.Dokdok ${ }^{\text {a }}$ \\ a Department of Fish Resources and Aquaculture, Faculty of Environmental Agricultural Sciences, El-Arish , \\ Suez Canal university. North Sinai, Egypt. \\ b Department of Aquaculture, Faculty of Fish Resources, Suez University, Suez, Egypt. \\ c Department of Biology, American University of Beirut Bliss St.
}

\begin{abstract}
The potential of canola meal and atriplex leaves meal in formulated diets for red tilapia (Oreochromis spp) was evaluated. Seven diets (30\% \pm .016 crude protein), $4640 \mathrm{kcal} \mathrm{GE} / \mathrm{kg}$ were formulated. Fish meal protein was substituted at the rate of 10, 20 and $30 \%$ with canola meal protein or atriplex leaves. A diet containing no plant sources served as the control. A diet containing $10 \%$ canola meal had significantly $(\mathrm{p} \leq 0.05)$ better weight gain and conversion values. All fish fed diets supplemented with 20 and $30 \%$ canola meal 10,20 and $30 \%$ atriplex demonstrated reduced growth and feed utilization efficiency ( $\mathrm{p} \geq 0.05)$. Except fish diet $10 \%$ canola, the growth rate and other nutritional parameter decreased with increasing inclusion levels of the two plant protein sources. Fish group fed diets control, $10 \%$ and $20 \%$ canola and $10 \%$ atriplex had a highest survival rate having their values $100 \%$ respectively. All water parameters tested were within permissible levels for Tilapia maximum growth so the use of canola meal up to $10 \%$ and up to $20 \%$ of atriplex is recommended, without adverse effect on Red Tilapia, fingerlings.
\end{abstract}

Keywords: unconventional plant proteins, canola meal, atriplex leaves, Red Tilapia

\section{Introduction}

Many studies have been conducted to evaluate the replacement of fish meal (FM) in practical diets for tilapia with cheap, locally available plant and animal protein sources (Nova et al., 1997; Fasakin et al., 1999, 2005; Richter et al., 2003; Boregson et al ., 2006 ; Hassanen et al., 2012, Hassanen et al ., 1995). The evaluation of feed ingredients is crucial to nutritional research and feed development for aquaculture species. In evaluating ingredients for use in aquaculture feeds, there are several important knowledge components that should be understood to enable the judicious use of particular ingredients in feed formulation (Enami, 2002 and 2003 a\&b,). This include information on 1- ingredients digestibility, 2- ingredients palatability and nutrient utilization and interference (Glencross et al., 2007). Progressive trend of aquaculture and fish farming, similar to other countries, makes us to choose an alternative protein sources (Hassanen, 1991).

The unconventional plant protein sources were chosen: canola meal and atriplex leaves. As fish meal is both expensive and difficult to obtain in Egypt and many developed countries, the alternative sources were tested at various inclusion rates, increasing to maximum possible levels compatible with providing a $30 \%$ protein diet, which has been shown to be the lowest level still providing reasonable growth in various tilapia species (Cruz and laudencia, 1977; Daivs and Stickney, 1978; Mazid et al., 1979. Although Cowey, (1979) have demonstrated that tilapia zilli require the same 10 essential amino acids as other fish no data are available as to the quantitative requirement in hybrid tilapia species.

The main objective was to determine maximum inclusion rates for the canola meal and atriplex leaves and the necessity for limitation arising from palatability or toxic factors. Given known amino acid profiles of the ingredient it was expected that, as a consequence of varying the quantity of the protein supplied by the various sources. To discover the most limiting amino acids and gain an indication as to their optimum levels under the condition provided.

\section{Materials and methods}

This experiment was carried out at the Mari culture Research Center (MRC) of the Suez Canal University, El-Arish, North Sinai- Egypt. Red Tilapia fingerlings (Oreochromis spp) with an average initial weight of $17.8 \pm 0.10 \mathrm{~g}$. were randomly selected and placed into $125 \mathrm{~L}$. Fiberglass tanks (10 fish / tank) at the beginning of adaptation of period). A flow rate of the water was $1.5 \mathrm{~L} / \mathrm{min} / \mathrm{tank}$. Each tank was equipped with an air stone and external stand pipe.

The experimental fish were regularly supplied with artificial feeds formulated from conventional and unconventional ingredients. The conventional ingredients were used for formulating the standard diet. A total of 7 experimental diets were formulated in the dry pelleted form as shown in table (3). The unconventional ingredients used in preparing the experimental diets were atriplex leaves meal and / or canola meal to evaluate the effect of incorporation of them at levels of 10,20 and $30 \%$ to substitute fish 
meal . Diet number (1) was considered as the control diet while the other six diets.(No 2 to 7 ) were as treatments. All diets were isonitrogenous $30 \pm 0.16$ crude protein and nearly isocaloric .

Adequate amount of Atriplex halimus were collected from the farm of Faculty of Environmental Agricultural Sciences, El-Arish. Leaves were dried aerobically for 5 days, then fully dried by used drying oven at $40^{\circ} \mathrm{C}$ for the $72 \mathrm{~h}$. The dry matter was ground by electric mill. The samples were preservation in the form of powder in plastic jars.

Canola meal was obtained from a local dealer. Feed ingredients were ground to fine particles; linseed oil was incorporated in order to reach the desirable total lipids and essential fatty acid levels. The feed mixture was processed into a pellet meal machine. The pellet was soft enough for the fish to take and retain. Particle size was $2 \mathrm{~mm}$ diameter, $4 \mathrm{~mm}$ length.

The first ten days of the experimental period was considered as an acclimatization period where the experimental feeds were given to the fish as $3 \%$ of the body weight per day .The actual period followed directly. The daily ration was offered three times a day at $9 \mathrm{am}, 12$ am and $3 \mathrm{pm}$ in three equal portions. The experimental diets were feed to duplicate groups. Each group of fish was weight at the beginning and once every 2 weeks and amount of diet was adjusted accordingly for the subsequent 2 weeks. Conversion index was calculated. At the end of the experimental period of 12 weeks after start, fish were weighing individually.

Feedstuffs were analyzed for macro nutrients and amino acid composition before used in diets formulation (table 1 and 2). Proximate composition (crude protein, fat, crude fiber, ash and moisture) of the dietary composition, experimental diets, and Red tilapia fingerlings body were determined according to A.O.A.C (1990), tables 4 and 7.

Amino acid of protein sources and experimental diets were determined by using amino acid analyzer according to methods described by Ibrahime (1974), tryptophan was determined calorimetrically in alkaline hydrolysis according to methods described by Blauth et al., 1963. Tables ( 2 and 5) show the essential amino acid of the protein sources and the experimental diets.
Dietary protein utilization of the experimental diets for growth was evaluate by determining protein efficiency ratio $(\mathrm{PER}=$ gain/protein intake $)$, protein productive value \% (PPV=100 body protein gain/protein intake) indices. Also the following indices were calculated:

FCR (Feed conversion ratio) = dry feed intake (g)/ wet weight gain $(\mathrm{g})$.

FE (feed efficiency) = wet weight gain $(g) /$ dry feed intake $(\mathrm{g})$.

SGR $(\% /$ day $)$ specific growth rate $=(\mathrm{Ln}$ final weight - Ln initial weight / number of days) x 100 .

Retained nutrient, protein, fat, ash and energy, = final body nutrient - Initial nutrient.

All data were subjected to analysis of variance (Steel and Torrie , 1980) and differences between means were tested by Duncan's multiple rang test (Duncan, 1955).

\section{Results:}

Essential amino acid composition, chemical score and essential amino acid index (EAAI) of the tested diets as compared with the requirement of Tilapia $(O$. niloticus) are presented in table (5). It can be noticed that trypotophan was the first limiting amino acid in all tested diets except in control diet. In diet No 4 (30\% canola meal), leucine was the second limiting amino acid, so the EAAI for this diet was 42.87. While for all diets EAAI was 100.00, 98.83, $98.65,99.47,95.38$, and 94.60 for groups control , $10 \%$ canola, $20 \%$ canola ,10\% atriplex , $20 \%$ atriplex and $30 \%$ atriplex leaves respectively .

At the end of the experimental period (12 weeks ), data concerning average initial and final body weight, weight gain, average daily gain (ADG), specific growth rate (SGR\%/ day), gain \% and survival rate are presented in table (6). The analysis of variance of these data indicated that the highest weight gain, ADG, SGR, Gain percentages and survival rate was obtained by the group fed diet $10 \%$ canola meal protein replacement of fish meal, followed in decreasing order by the control group (diet No 1) and diets No 5,6,7,3 and 4 where the gain percentages were $83.60,79.16,73.62,64.94,60.17$ and $57.22 \%$ respectively .

Table 1. The approximate analysis of the ingredients used in feed formulation for Red Tilapia (Oreochromis spp) on DM basis

\begin{tabular}{lccccccc}
\hline \multicolumn{1}{c}{ kcal/ME2 kg } & $\mathrm{kcal} / \mathrm{GE} 1 \mathrm{~kg}$ & NFE & Ash & CF & EE & CP & Ingredients \% \\
\hline Conventional & & & & & & & \\
\hline Fish meal & 70.00 & 8.50 & 0.60 & 16.40 & 4.50 & 4986.25 & 3491.60 \\
Yellow corn & 8.50 & 3.60 & 2.30 & 1.30 & 84.30 & 4284.45 & 1968.30 \\
Wheat bran & 16.40 & 4.00 & 9.90 & 5.30 & 64.40 & 4276.60 & 1990.00 \\
Soybean meal & 44.00 & 1.10 & 7.30 & 6.30 & 41.30 & 4533.95 & 2464.80 \\
Rice bran & 14.40 & 2.10 & 10.80 & 5.40 & 67.30 & 4136.05 & 1806.40 \\
Unconventional & & & & & & & \\
Canola meal & 37.19 & 3.50 & 10.70 & 6.80 & 41.81 & 4532.39 & 2399.37 \\
Atriplex leaves & 20.70 & 7.40 & 4.40 & 25.50 & 42.00 & 3724.85 & 2071.30 \\
\hline
\end{tabular}


Table 2. Amino acid contents of some ingredients used in feed formulation for Red Tilapia (Oreochromis spp) as dietary protein $\%$.

\begin{tabular}{|c|c|c|c|c|c|c|c|c|c|c|}
\hline \multirow[b]{2}{*}{ Ingredients } & \multicolumn{10}{|c|}{ Essential Amino Acid } \\
\hline & Leu & Isl & Phe & Met & Val & Thr & Arg & His & Lys & try \\
\hline \multicolumn{11}{|l|}{ Conventional } \\
\hline fish meal & 6.29 & 4.41 & 3.97 & 2.57 & 4.78 & 3.78 & 5.88 & 2.47 & 5.82 & 0.84 \\
\hline $\begin{array}{l}\text { Soybean } \\
\text { meal }\end{array}$ & 3.67 & 2.50 & 2.67 & 0.70 & 2.43 & 1.98 & 3.91 & 1.32 & 3.10 & 0.62 \\
\hline Yellow corn & 1.20 & 0.36 & 0.46 & 0.18 & 0.49 & 0.36 & 0.48 & 0.26 & 0.26 & 0.07 \\
\hline Wheat bran & 0.89 & 0.65 & 0.27 & 0.34 & 0.53 & 0.55 & 0.68 & 0.88 & 0.20 & 0.30 \\
\hline \multicolumn{11}{|c|}{ Unconventional } \\
\hline $\begin{array}{l}\text { Caonla } \\
\text { meal }\end{array}$ & 2.62 & 1.70 & 1.43 & 0.76 & 2.04 & 1.63 & 2.15 & 1.16 & 2.07 & 0.50 \\
\hline $\begin{array}{l}\text { Atriplex } \\
\text { leaves }\end{array}$ & 1.25 & 0.85 & 0.68 & 1.27 & 1.11 & 0.73 & 0.53 & 0.39 & 0.89 & 0.62 \\
\hline
\end{tabular}

Table 3. Composition of diets containing various percentage of Atriplex and canola meal as replacement for fish meal protein

\begin{tabular}{llllllll}
\hline & \multicolumn{1}{c}{ control } & \multicolumn{2}{c}{ Canola meal } & \multicolumn{5}{c}{ Atriplex leaves } \\
\cline { 2 - 8 } Ingredients & \multicolumn{1}{c}{2} & \multicolumn{1}{c}{2} & 3 & 4 & 5 & 6 & 7 \\
\hline Fishmeal (70\%CP) & 26.00 & 23.40 & 20.80 & 18.20 & 23.40 & 20.80 & 18.20 \\
\hline Soybean meal(44\%CP) & 15.00 & 15.00 & 15.00 & 15.00 & 15.00 & 15.00 & 15.00 \\
\hline Canola meal (37.19\%CP) & - & 4.89 & 9.78 & 14.67 & & - & - \\
\hline Atriplex leaves & - & - & - & - & 8.80 & 17.60 & 26.40 \\
\hline Wheat bran & 16.00 & 10.00 & 10.00 & 10.00 & 16.00 & 16.00 & 16.00 \\
\hline Rice bran & 6.00 & 10.00 & 10.00 & 10.00 & 14.5 .00 & 16.3 .00 & 17.4 .00 \\
\hline Yellow corn & 30.00 & 29.71 & 27.42 & 25.13 & 15.30 & 7.30 & - \\
\hline Vit . Mix & 2.00 & 2.00 & 2.00 & 2.00 & 2.00 & 2.00 & 2.00 \\
\hline Min . Mix & 2.00 & 2.00 & 2.00 & 2.00 & 2.00 & 2.00 & 2.00 \\
\hline Linseed oil & 3.00 & 3.00 & 3.00 & 3.00 & 3.00 & 3.00 & 3.00 \\
\hline Total & 100 & 100 & 100 & 100 & 100 & 100 & 100 \\
\hline
\end{tabular}

Table 4. Nutrient composition of diets containing various percentages of Atriplex leaves or Canola meal as replacement for fish meal protein (on dry matter basis

\begin{tabular}{|c|c|c|c|c|c|c|c|}
\hline \multirow[t]{2}{*}{ Nutrient } & \multirow[t]{2}{*}{ Control } & \multicolumn{3}{|c|}{ Canola meal } & \multicolumn{3}{|c|}{ Atriplex leaves } \\
\hline & & $10 \%$ & $20 \%$ & $30 \%$ & $10 \%$ & $20 \%$ & $30 \%$ \\
\hline $\mathrm{CP}$ & 30.26 & 30.36 & 30.13 & 29.96 & 30.74 & 30.32 & 29.85 \\
\hline E.E & 7.21 & 6.98 & 6.67 & 6.67 & 7.28 & 7.46 & 7.65 \\
\hline $\mathrm{CF}$ & 4.11 & 4.49 & 5.01 & 4.32 & 5.06 & 5.44 & 5.68 \\
\hline Ash & 7.35 & 5.39 & 5.4 & 5.4 & 7.57 & 6.07 & 6.23 \\
\hline $\mathrm{NFE}^{1}$ & 51.07 & 52.78 & 52.79 & 53.65 & 49.85 & 50.71 & 50.59 \\
\hline $\mathrm{GE}^{2}$ & 4606 & 4666 & 4645 & 4642 & 4601 & 4664 & 4660 \\
\hline $\mathrm{ME}^{3}$ & 2585.56 & 2586.92 & 2553.31 & 2560.44 & 2570.86 & 2590.64 & 2585.59 \\
\hline $\mathrm{P} / \mathrm{E}^{4}$ & 118.97 & 117.36 & 118.00 & 117.01 & 119.57 & 117.04 & 115.45 \\
\hline $\begin{array}{ll}1- & \mathrm{NFE}: \\
2- & \mathrm{GE}= \\
3- & \mathrm{ME}= \\
4- & \mathrm{P} / \mathrm{E} \mathrm{r}\end{array}$ & $\begin{array}{l}\text { ree extract= } \\
\text { y (Kcal/kg d } \\
\text { ble energy (1 } \\
\text { rotein } / \mathrm{kcal}\end{array}$ & $\begin{array}{l}0-(\mathrm{CP} \%+\mathrm{EE} \\
\mathrm{l} / \mathrm{kg} \text { diet })\end{array}$ & & & & & \\
\hline
\end{tabular}


Table 5. Essential amino acids composition, chemical score and essential amino acids index of the tested diets (\% Dietary protein)

\begin{tabular}{|c|c|c|c|c|c|c|c|c|c|c|c|c|c|c|c|}
\hline \multirow[b]{3}{*}{ E.A.A } & \multirow{3}{*}{$\begin{array}{c}\text { Tilapia } \\
\text { requirements } \\
\text { of E AA }\end{array}$} & \multirow{2}{*}{\multicolumn{2}{|c|}{ Control }} & \multicolumn{6}{|c|}{ Canola meal\% } & \multicolumn{6}{|c|}{ Atriplex leaves\% } \\
\hline & & & & \multicolumn{2}{|c|}{10} & \multicolumn{2}{|c|}{20} & \multicolumn{2}{|c|}{30} & \multicolumn{2}{|c|}{10} & \multicolumn{2}{|c|}{20} & \multicolumn{2}{|c|}{30} \\
\hline & & E.A.S & $\mathrm{CS}$ & E.A.A & $\mathrm{CS}$ & E.A.A & $\mathrm{CS}$ & E.A.A & $\mathrm{CS}$ & E.A.A & $\mathrm{CS}$ & E.A.A & $\mathrm{CS}$ & E.A.A & $\mathrm{CS}$ \\
\hline Leu & 6.45 & 9.15 & 141.86 & 9.00 & 139.53 & 8.86 & 137.36 & 2.61 & 40.46 & 8.78 & 136.12 & 8.20 & 127.13 & 7.90 & 122.48 \\
\hline Isol & 3.45 & 5.97 & 173.04 & 5.87 & 170.14 & 5.79 & 167.82 & 1.70 & 49.27 & 6.01 & 174.20 & 5.68 & 164.64 & 5.59 & 162.03 \\
\hline Phe & 3.39 & 5.51 & 162.54 & 5.44 & 160.47 & 5.34 & 157.52 & 1.56 & 46.01 & 5.40 & 159.29 & 5.02 & 148.10 & 4.88 & 144.38 \\
\hline Meth & 0.3 & 3.11 & 1036.66 & 3.06 & 1020.00 & 2.97 & 990.00 & 0.86 & 268.90 & 3.44 & 1146.70 & 3.56 & 1187 & 3.75 & 1250 \\
\hline Val & 4.02 & 6.26 & 155.72 & 6.17 & 153.48 & 6.10 & 151.74 & 1.80 & 44.78 & 6.19 & 153.93 & 5.89 & 146.51 & 5.79 & 144.03 \\
\hline The & 3.33 & 5.04 & 151.35 & 4.96 & 148.94 & 4.91 & 147.45 & 1.45 & 43.54 & 4.99 & 149.84 & 4.70 & 141.40 & 4.60 & 138.14 \\
\hline Arg & 5.04 & 8.02 & 159.13 & 7.82 & 159.12 & 7.69 & 152.58 & 2.26 & 44.84 & 7.71 & 152.98 & 7.00 & 138.89 & 6.67 & 132.34 \\
\hline His & 2.1 & 3.64 & 173.33 & 3.52 & 167.62 & 3.50 & 166.66 & 1.04 & 49.52 & 3.61 & 171.90 & 3.37 & 160.48 & 3.29 & 156.70 \\
\hline Lys & 5.94 & 7.24 & 121.88 & 7.23 & 121.72 & 7.10 & 119.53 & 2.08 & 35.02 & 7.35 & 123.74 & 6.98 & 117.50 & 6.84 & 109.90 \\
\hline Try & 2.52 & 2.78 & 110.3 & 2.24 & 88.89 & 2.20 & 87.30 & 0.38 & 15.10 & 2.39 & 94.84 & 1.95 & 62.30 & 1.45 & 57.40 \\
\hline E.A.A.I & & \multicolumn{2}{|c|}{100} & \multicolumn{2}{|c|}{98.83} & \multicolumn{2}{|c|}{98.65} & \multicolumn{2}{|c|}{42.87} & \multicolumn{2}{|c|}{99.47} & \multicolumn{2}{|c|}{95.38} & \multicolumn{2}{|c|}{94.60} \\
\hline
\end{tabular}


Table 6. Chemical score (CS) and limiting amino acids for Red Tilapia in unconventional ingredients used in the present study (As dietary protein \%).

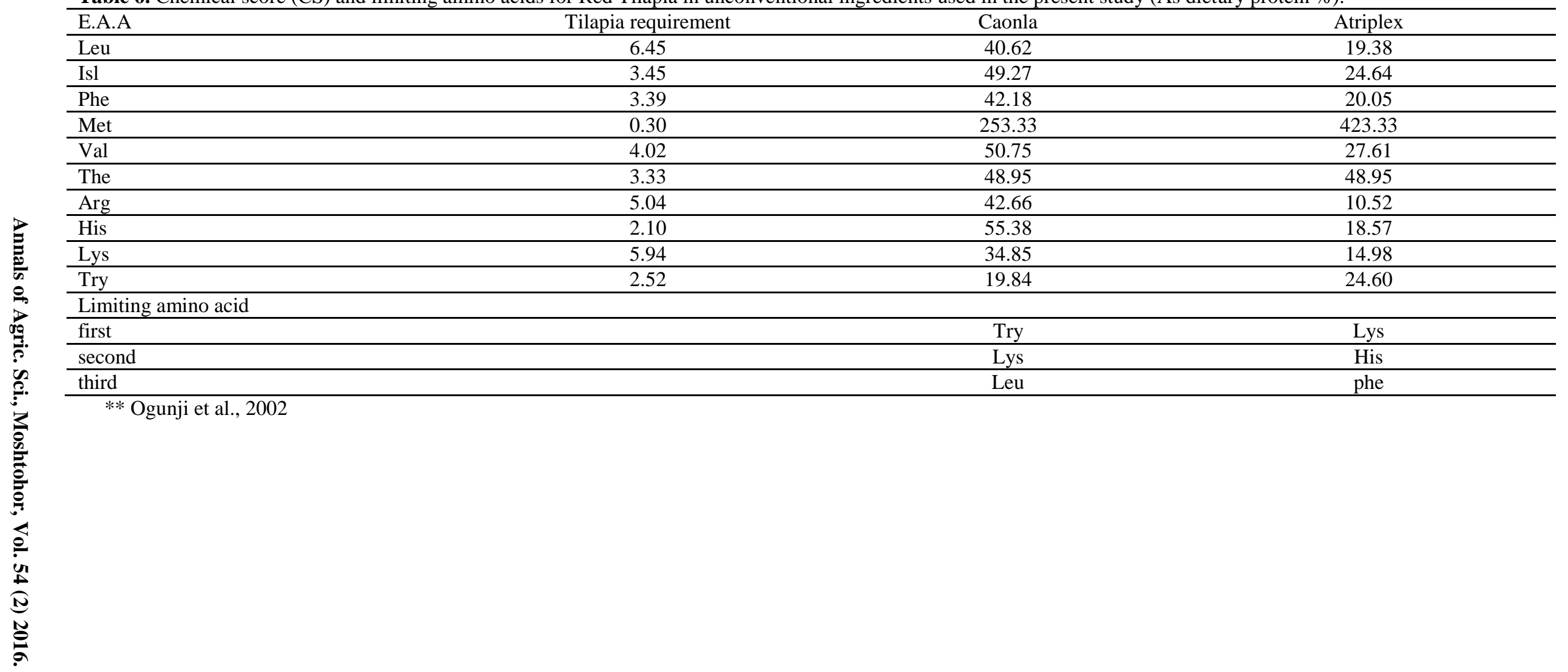


Body composition, dry matter, crude protein (CP), ether extract (EE), ash and energy content of Red Tilapia at the beginning and the end of the experimental period (12 week) are given in table (7). As compared with the control group (diet 1) there were significant increases $(\mathrm{P} \leq 0.05)$ in protein contents for groups fed $10 \%$ canola meal, $10 \%$ atriplex, 20 and $30 \%$ atriplex and canola meal. The highest fat contents were obtained by the $30 \%$ atriplex leaves which associated with the low protein content. The energy content as $\mathrm{GE}(\mathrm{Kcal} / \mathrm{g})$ dry matter fish at the end of the experiment were significantly higher $(\mathrm{P} \leq 0.05)$ in fish group fed $10 \%$ canola meal and $10 \%$ atriplex leaves than that of the control group .

Feed intake, CP, fat and energy intake of the experimental diets are present in table (8), In all experiment it was clear that replacement of fish meal protein by other unconventional protein (canola meal or atriplex) sources increased the nutrient intake. However, the analysis of variance indicated that the replacement of fish meal protein by 20 or $30 \%$ canola meal protein showed the highest feed intake and followed by 10, 20\% atriplex leaves and control diet.

Protein, fat, ash and energy retained as presented in table (8). The $10 \%$ canola meal and $10 \%$ atriplex leaves groups (diet No 2 and 5), showed higher protein and energy retained than the other groups. Differences were insignificant $(\mathrm{p} \leq 0.05)$ among groups fed diets 20 and $30 \%$ canola meal respectively $(\mathrm{P} \leq 0.05)$.

Protein and energy retained for diets 2 and 5 as percentage of the control were 112.1 and $106.25 \%$ for protein and 102.10 and $107.08 \%$ for energy respectively. Diets 4(30\% canola meal) 7 (30\% atriplex leaves exhibited a lower protein and energy retained.

Feed conversion ratio (FCR), feed efficiency (FE $\%)$ and nutrient utilization are presented in table (9). Results showed that there are significant differences ( $\mathrm{P} \leq 0.05$ ) between all the experimental groups which fed the tested diets in FCR ,FE\%,PER and PPV\%. The averages of FCR of fish fed on diets 1 and 2 had a significantly $(\mathrm{P} \leq 0.05)$ higher than the other dietary groups. The groups of fish fed diets 2 and 5 showed the highest FE\%, 74.14 and $60.40 \%$ respectively. The average of PER was 2.57, 2.00, 1.8,1.72,1.4 and 1.22 for group of fish on diets $2,1,5,6,7,3$ and 4 respectively. Statistical analysis revealed that diets 2 and 1 (control) had a significantly $(\mathrm{P} \leq 0.05)$ higher PER than the rest of groups. Similarly, PPV \% was found also to be the highest in group fed 2,5and having their values 43.18, 32.57and 32.30 respectively.

Results illustrated in table (10) indicated that the feed costs per $\mathrm{kg}$ gain in weight were the lowest in group 2 (10\% canola meal followed in an increasing order by groups 4, 3, 7, 1, 6 and 5 respectively.

\section{Discussion}

The experiment was conducted to investigate new sources of unconventional plant protein in Red Tilapia (Oreochromis spp) diets. Study examined the effects of partial substitution of canola meal and/or atriplex leaves at levels 10, 20 and $30 \%$ for each ingredient to replacement of fish meal protein. So the basic of this study was to develop practical diets for Red Tilapia from the available, inexpensive local ingredients in North Sinai Governorate.

In this study, based primary on the proximate analysis of the canola meal, it is contain $10.70 \%$ fiber (table, 1) indicated that increased dietary fiber can reduce growth in Red Tilapia.

These results are in agreement with Shiau and Kowk (1989) in Tilapia . Liang (2000) and Yigit et al. (2012) reported that fiber can induce a faster passage rate, reducing the opportunity for digestion and increasing endogenous nitrogen loss through abrasive action or binding endogenous protein. Lie and Robinson (1994) found that feeds for channel catfish can contain at least $25 \%$ canola meal by replacement of soybean meal without detrimental effects. Davies et al., (1990) suggested an inclusion limit of $15 \%$ canola meal in the diet of Tilapia (Oreochromis mossambicus) fry. The differences of these studies from the present study could be due to different fish species and glucosinolate content of canola meal.

Groups of fish fed $20 \%$ and $30 \%$ canola meal significantly $(p \geq 0.05)$ showed lower body weight than that in fish group fed $10 \%$ canola meal. These increases of canola meal protein with fish deleterious effects of glucosinolate on growth inhibition . Results are in agreement with Burel et al., (2000) who reported that $300 \mathrm{~g} / \mathrm{kg}$ rapeseed and containing a low level of glucosinolate $(5 \mathrm{~m} \mathrm{~mole} / \mathrm{g})$ could be used in practical rainbow trout diets without deleterious effect.

In the present study, feed intake, protein, fat and energy intake were lower in fish fed low level $(10 \%)$ of canola meal than the other groups of fish fed on 20 and $30 \%$, where these parameter increased with increasing levels of canola meal in diets. These results were contrast to studies of Shafaeipour et al., (2008) who showed that feed intake decreased with increasing dietary canola meal level in the trout. Similar trend with the study of Cheng et al., (2010) who observed an increasing in feed intake with increasing dietary canola meal level in Japanese sea bass. Differences between our study and another studies may be due to the use of different species and size .

Also, in our study results obtained of FCR, FE\%, PER, PPV\% and EPV\% clear the addition of 20 and $30 \%$ canola meal to diets resulted in lower for these parameters following lower protein, fat and energy retained. 
In Atriplex leaves diets (5, 6 and 7). Accordingly, any differences in the performance of fish received such diets could be attributed to the quality and feeding value of the levels Atriplex leaves material $(10,20$ and $30 \%)$ used.

The obtained results clearly showed that, the replacement up to $20 \%$ FM by Atriplex leaves meal allowed FI, FCR and PER similar to those exhibited by control groups (FM based diet) and the same trend was obtained for growth parameters ( BW,WG and SGR \%/ day). The highest replacing levels (more than $20 \%$ ) significantly reduced FI, PER, FCR)and also negatively affected growth parameters (BW, WG and SGR \%/day). These results suggests that the protein, ash and energy retained for diet No 7 (30\% atriplex ) is lower than that of FM (basal diet) for Red Tilapia . Possible reasons for the reduced feed intake, protein intake, fat, ash and energy intake and growth parameters recorded at the highest replacing levels of FM by Atriplex more than (20\%). Also, it may be related to the high-crude fiber, presence of identified or unidentified anti-nutritional factors and poor palatability of $30 \%$ atriplex which reduced FI and adversed FCR and PER .Results are in agreement with (Soltan et al., 2008).

Atriplex leaves meal has been used to replace fish meal partially in diets of (Oreochromis aureus) (Youssif et al., 1994) but the results were negative where the performance parameter decreased significantly by increasing the level of Atriplex leaves meal. Artichoke leaves waste meal (Cynaro scolynnus) has been successfully used in diets of Red Tilapia.

In conclusion, all unconventional plant sources used in the present study can be used as a source of protein which can be include safely with fish meal in red tilapia diets aiming to reduce the costs

Table 7. Average of body weight, daily gain (ADG), specific growth rate (SGR) and gain \% of Red tilapia.

\begin{tabular}{lccccccc}
\hline \multicolumn{1}{c}{ diet No } & 1 & 2 & 3 & 4 & 5 & 6 & 7 \\
\hline Replacement & Control & \multicolumn{3}{c}{ Canola meal } & \multicolumn{3}{c}{ Atriplex leaves } \\
\cline { 2 - 9 } Unconventional protein \% & 0 & 10 & 20 & 30 & 10 & 20 & 30 \\
\hline Initial weight & $17.80^{\mathrm{a}}$ & $17.80^{\mathrm{a}}$ & $17.60^{\mathrm{a}}$ & $17.60^{\mathrm{a}}$ & $17.80^{\mathrm{a}}$ & $17.70^{\mathrm{a}}$ & $17.80^{\mathrm{a}}$ \\
(g/fish) & \pm 0.08 & \pm 0.11 & \pm 0.14 & \pm 0.06 & \pm 0.03 & \pm 0.01 & \pm 0.23 \\
\hline & $32.68^{\mathrm{b}}$ & $33.85^{\mathrm{a}}$ & $28.19^{\mathrm{f}}$ & $27.67^{\mathrm{g}}$ & $31.89^{\mathrm{c}}$ & $30.73^{\mathrm{d}}$ & $29.36^{\mathrm{e}}$ \\
final weight(g/fish) & $\pm 0.07^{\mathrm{y}}$ & $\pm 0.13 \pm$ & $\pm 0.09 \pm$ & $\pm 0.03 \pm$ & $\pm 0.18 \pm$ & $\pm 0.12 \pm$ & $\pm 0.14 \pm$ \\
\hline weight gain & $14.88^{\mathrm{b}}$ & $16.05^{\mathrm{a}}$ & $10.59^{\mathrm{f}}$ & $10.07^{\mathrm{g}}$ & $14.09^{\mathrm{c}}$ & $13.03^{\mathrm{d}}$ & $11.56^{\mathrm{e}}$ \\
(g/fish) & \pm 0.01 & \pm 0.01 & $\pm 0.05^{\mathrm{y}}$ & \pm 0.02 & \pm 0.22 & \pm 0.13 & \pm 0.09 \\
\hline Average daily gain & $0.18^{\mathrm{b}}$ & $0.19^{\mathrm{a}}$ & $0.13^{\mathrm{f}}$ & $0.12^{\mathrm{g}}$ & $0.17^{\mathrm{c}}$ & $0.15^{\mathrm{d}}$ & $0.14^{\mathrm{e}}$ \\
(g/fish) & \pm 0.001 & \pm 0.001 & \pm 0.001 & \pm 0.001 & \pm 0.003 & \pm 0.002 & \pm 0.001 \\
\hline Specific & $0.72^{\mathrm{b}}$ & $0.76^{\mathrm{a}}$ & $0.56^{\mathrm{f}}$ & $0.54^{\mathrm{g}}$ & $0.69^{\mathrm{c}}$ & $0.655^{\mathrm{d}}$ & $0.599^{\mathrm{e}}$ \\
growth rate(\%day) & \pm 0.003 & \pm 0.004 & \pm 0.005 & \pm 0.01 & \pm 0.01 & \pm 0.005 & \pm 0.01 \\
\hline Gain\% & 83.60 & 90.17 & 60.17 & 57.22 & $79.16^{2}$ & 73.62 & 64.94 \\
\hline
\end{tabular}

Table 8. Chemical composition and energy content of whole body of Red Tilapia as affected by different treatments (DM basis)

\begin{tabular}{lccccccc}
\hline diet No & 1 & 2 & 3 & 4 & 5 & 6 & 7 \\
\hline Replacement & Control & \multicolumn{3}{c}{ Canola meal } & \multicolumn{3}{c}{ Atriplex leaves } \\
\cline { 2 - 8 } Unconventional protein \% & 0 & 10 & 20 & 30 & 10 & 20 & 30 \\
\hline & 24.62 & 23.88 & 23.45 & 23.65 & 23.58 & 22.77 & 22.95 \\
DM & & \pm 0.04 & \pm 0.14 & \pm 0.01 & \pm 0.02 & \pm 0.31 & \pm 0.04 \\
\hline & 65.50 & $68.83^{\mathrm{c}}$ & $74.08^{\mathrm{ab}}$ & $71.75^{\mathrm{abc}}$ & $71.05^{\mathrm{bc}}$ & $74.67^{\mathrm{a}}$ & $70.50^{\mathrm{d}}$ \\
$\mathrm{CP}$ & & \pm 0.67 & \pm 0.78 & \pm 0.03 & \pm 0.82 & \pm 0.04 & \pm 0.43 \\
\hline & 13.66 & $14.42^{\mathrm{f}}$ & $12.76^{\mathrm{d}}$ & $11.33^{\mathrm{abc}}$ & $14.43^{\mathrm{d}}$ & $14.19^{\mathrm{b}}$ & $14.27^{\mathrm{cd}}$ \\
$\mathrm{EE}$ & & \pm 0.13 & \pm 0.23 & \pm 0.29 & \pm 0.46 & \pm 0.32 & \pm 0.59 \\
\hline & 18.76 & $16.10^{\mathrm{bc}}$ & $12.76^{\mathrm{abc}}$ & $16.10^{\mathrm{abc}}$ & $14.84^{\mathrm{d}}$ & $14.04^{\mathrm{b}}$ & $14.66^{\mathrm{abc}}$ \\
Ash & & \pm 0.19 & \pm 0.23 & \pm 0.23 & \pm 0.46 & \pm 0.39 & \pm 0.59 \\
\hline & 5.17 & $5.13^{\mathrm{bc}}$ & $5.39^{\mathrm{b}}$ & $5.13^{\mathrm{c}}$ & $5.42^{\mathrm{b}}$ & $5.75^{\mathrm{a}}$ & $5.05^{\mathrm{c}}$ \\
$\mathrm{GE}(\mathrm{kcal} / \mathrm{g})$ & & \pm 0.06 & \pm 0.13 & \pm 0.20 & \pm 0.04 & \pm 0.06 & \pm 0.06 \\
\hline
\end{tabular}


Table 9. Intake of feed and retained of protein, fat, ash and energy of Red Tilapia at the end of the experiment:

\begin{tabular}{|c|c|c|c|c|c|c|c|}
\hline \multirow{3}{*}{$\begin{array}{l}\text { diet No } \\
\text { Replacement } \\
\text { Unconventional protein } \%\end{array}$} & \multirow{3}{*}{$\begin{array}{c}\frac{1}{\text { Control }} \\
0\end{array}$} & 2 & \multicolumn{2}{|c|}{$\frac{3}{\text { Canola meal }}$} & \multicolumn{3}{|c|}{\begin{tabular}{|cc}
5 & 6 \\
& Atriplex leaves \\
\end{tabular}} \\
\hline & & \multicolumn{3}{|c|}{ Canola meal } & \multicolumn{3}{|c|}{ Atriplex leaves } \\
\hline & & 10 & 20 & 30 & 10 & 20 & 30 \\
\hline Feed Intake (g/fish) & $24.55^{\mathrm{e}}$ & $20.54^{\mathrm{g}}$ & $26.47^{\mathrm{b}}$ & $29.20^{\mathrm{a}}$ & $25.90^{\mathrm{c}}$ & $25.02^{\mathrm{cd}}$ & $22.54^{\mathrm{f}}$ \\
\hline Protein intake (g/fish) & $7.43^{\mathrm{de}}$ & $6.23^{\mathrm{g}}$ & $7.97^{\mathrm{ab}}$ & $8.75^{\mathrm{a}}$ & $7.83^{\mathrm{c}}$ & $7.59^{\mathrm{d}}$ & $6.73^{\mathrm{f}}$ \\
\hline Fat intake (g/fish) & $1.77^{\mathrm{d}}$ & $1.43^{\mathrm{f}}$ & $1.76^{\mathrm{d}}$ & $1.94^{\mathrm{a}}$ & $1.88^{\mathrm{b}}$ & $1.87^{\mathrm{bc}}$ & $1.72^{\mathrm{e}}$ \\
\hline Energy intake (kcal,GE) & $113.10^{\mathrm{d}}$ & $95.84^{\mathrm{fg}}$ & $121.76^{\mathrm{b}}$ & $134.32^{\mathrm{a}}$ & $119.17^{\mathrm{c}}$ & $116.69^{\mathrm{e}}$ & $105.4^{\mathrm{f}}$ \\
\hline Protein retained $(\mathrm{g})$ & $2.40^{\mathrm{c}}$ & $2.69^{\mathrm{a}}$ & $1.94^{\mathrm{efg}}$ & $1.80^{\mathrm{ef}}$ & $2.55^{\mathrm{ab}}$ & $2.12^{\mathrm{d}}$ & $1.84^{\mathrm{e}}$ \\
\hline Fat retained $(\mathrm{g})$ & $0.53^{\mathrm{ab}}$ & $0.41^{\mathrm{d}}$ & $0.26^{\mathrm{f}}$ & $0.48^{\mathrm{c}}$ & $0.43^{\text {ed }}$ & $0.41^{\mathrm{d}}$ & $0.56^{\mathrm{a}}$ \\
\hline Ash retained $(\mathrm{g})$ & $0.43^{\mathrm{a}}$ & $0.19^{\mathrm{ef}}$ & $0.26^{\mathrm{b}}$ & $0.16^{\mathrm{e}}$ & $0.20^{\mathrm{bcd}}$ & $0.22^{\mathrm{bc}}$ & $0.14^{\text {efg }}$ \\
\hline
\end{tabular}

Table 10. Feed conversion ratio (FCR), Feed efficiency (FE \%), protein efficiency ratio (PER), Protein productive value (PPV \%) and Energy productive value (EPV\%) for Red Tilapia

\begin{tabular}{lccccccc}
\hline diet No & 1 & 2 & 3 & 4 & 5 & 6 & 7 \\
\hline Replacement & Control & \multicolumn{3}{c}{ Canola meal } & & Atriplex leaves \\
Unconventional protein $\%$ & 0 & 10 & 20 & 30 & 10 & 20 & 30 \\
\hline FCR & $1.65^{\mathrm{e}}$ & $1.28^{\mathrm{f}}$ & $2.5^{\mathrm{b}}$ & $2.90^{\mathrm{a}}$ & $1.84^{\mathrm{cd}}$ & $1.92^{\mathrm{c}}$ & $1.95^{\mathrm{c}}$ \\
\hline FE\% & $60.60^{\mathrm{b}}$ & $74.14^{\mathrm{a}}$ & $40.01^{\mathrm{f}}$ & $36.44^{\mathrm{g}}$ & $54.40^{\mathrm{c}}$ & $53.08^{\mathrm{cd}}$ & $51.29^{\mathrm{e}}$ \\
\hline PER & $2.00^{\mathrm{d}}$ & $2.57^{\mathrm{a}}$ & $1.49^{\mathrm{g}}$ & $1.22^{\mathrm{h}}$ & $1.80^{\mathrm{e}}$ & $1.72^{\mathrm{f}}$ & $1.72^{\mathrm{f}}$ \\
\hline PPV\% & $32.30^{\mathrm{b}}$ & $43.18^{\mathrm{a}}$ & $24.34^{\mathrm{f}}$ & $20.57^{\mathrm{g}}$ & $32.57^{\mathrm{c}}$ & $27.93^{\mathrm{d}}$ & $27.34^{\mathrm{e}}$ \\
\hline EPV\% & $15.64^{\mathrm{b}}$ & $18.84^{\mathrm{a}}$ & $9.69^{\mathrm{f}}$ & $9.65^{\mathrm{g}}$ & $16.03^{\mathrm{c}}$ & $11.21^{\mathrm{e}}$ & $13.03^{\mathrm{d}}$ \\
\hline
\end{tabular}

Table 11. Feed cost per kg of Red Tilapia fed experimental diets.

\begin{tabular}{|c|c|c|c|c|c|c|c|}
\hline \multirow{3}{*}{$\begin{array}{l}\text { diet No } \\
\text { Replacement } \\
\text { Unconventional protein } \%\end{array}$} & 1 & 2 & 3 & 4 & 5 & 6 & 7 \\
\hline & Control & \multicolumn{3}{|c|}{ Canola meal } & \multicolumn{3}{|c|}{ Atriplex leaves } \\
\hline & 0 & 10 & 20 & 30 & 10 & 20 & 30 \\
\hline Cost per kg diet L.E & 5.17 & 4.93 & 4.69 & 4.45 & 4.83 & 4.49 & 4.15 \\
\hline $\begin{array}{l}\text { Consumed feed to produce } \mathrm{kg} \\
\text { fish,kg }\end{array}$ & .75 & .61 & .56 & .56 & .81 & .81 & .77 \\
\hline Feed cost/kg fresh fissile & 3.88 & 3.00 & 2.63 & 2.49 & 3.91 & 3.64 & 3.19 \\
\hline $\begin{array}{l}\text { Relative } \% \text { of feed cost } / \mathrm{kg} \\
\text { fish }\end{array}$ & 155.8 & 120.5 & 105.6 & 100 & 157.0 & 146.2 & 128.1 \\
\hline Feed cost / kg gain, L.E & 8.5 & 6.3 & 7.0 & 6.9 & 8.9 & 8.6 & 8.1 \\
\hline $\begin{array}{l}\text { Relative } \% \text { of feed cost of } \mathrm{kg} \\
\text { gain }\end{array}$ & 135.0 & 100 & 111.0 & 109.5 & 141.0 & 136.0 & 128.6 \\
\hline
\end{tabular}

2- Feed intake per fish period / final weight, $\mathrm{kg} / \mathrm{kg}$.

1- Step 1X step 2.

4- Respective figure for steps $3 /$ lower figure in this step.

5- feed intake per $\mathrm{kg}$ gain $\mathrm{X}$ step 1

6- Respective figure for step 5/lower figure in this step.

\section{References}

AOAC (1990). Official methods of analysis of the association of official analytical chemistry (15th ed., p. 17). Arlington, VA: Association of Official Analytical Chemists.

Borgeson, T. L., Racz, V. J., Wilkie, D. C. White, L. J. and Drew, M. D. (2006): Effect of replacement fish meal and oil with simple or complex mixtures of vegetable ingredients in diets fed to Nile tilapia (Oreochromis niloticus). Aquaculture Nutrition 12: 141149.

Blauth, I., Opieñska., Charêdziñski M. and Berbeæ, H. (1963): Anew rapid method of determining tryptophan. Anal. Bioch. 6: 60-76.
Burel, C., Boujard, T., Escaffre, A. M., Kaushik, S. J., Boeuf, G., Mol, K. A., and KuÈhn, E. R. (2000). Dietary low-glucosinolate rapeseed meal affects thyroid status and nutrient utilization in rainbow trout (Oncorhynchus mykiss).British Journal of Nutrition, 83(06), 653-664.

Cheng, Z., Ai, Q., Mai, K., Xu, W., Ma, H., Li, Y. and Zhang, J. (2010): Effects of dietary canola meal on growth performance, digestion and metabolism of Japanese sea bass, Lateo labrax japonicus. Aquaculture; 305: 102108.

Cowey, C.B. (1979), Protein and amino acid requirements of finfish. In Finfish nutrition and fish feed technology, edited by J.E. Halver and 
K. Tiews. Schr. Bundesforschungsanst. Fisch. Hamb., (14/15) Vol.1:3-16.

Cruz, E. M. and Laudencia, R, L. (1977). Protein requirements of Tilapia mossambica fmgerlings. Kalikasan,tf 177-182.

Davies, S.J., McConnell, S., Bateson, R.I. (1990): Potential of rapeseed meal as an alternative protein source in complete diets for tilapia (Oreochromis mossambicus Peters). Aquaculture; 87:145-154.

Davis, A. T. and R. R. Stickney. (1978). Growth response of Tilapia aurea to dietary protein quality and quantity. Trans. Am. Fish. Soc., 107: 479-483.

Duncan, D. B. (1955): Multiple range and multiple F-test Biometrics. 11:1- 42.

Enami, H. R. (2002): Potential use of Iranian rapeseed meal in aquaculture

$2^{\text {nd }}$ scientific seminar on using rapeseed meal in livestock, poultry and aquatic animals, Tehran, Iran.

Enami, H. R. (2003a): Chemical properties of Iranian canola meal: Nutritional and anti-nutritional compounds. Damdaran-e- Iran, 43:13:15

Enami , H. R. (2003b):Evaluation of nutritional value of canola meal as a protein source in fish and shrimp diets. Damdaran -e- Iran, 47:2729.

Fasakin, E. A., Serwata, R. D. and Davies, S. J. (2005): Comparative utilization of rendered animal derived products with or without composite mixture of soybean meal in hybrid tilapia (Oreochromis niloticus $x \quad O$. mossambicus) diets. Aquaculture 249:329-338.

Fasakin, E. A., Balogun, A. M. and Fasuru, B. E. (1999): Use of duckweed, Spirodela polyrrhiza L. Schleiden, as a protein feed stuff in practical diets for tilapia, Oreochromis niloticus L. Aquaculture Res., 30:313-318.

Glencross, B. D., Booth, M. and Allan, G. L. (2007): A feed is only as good as its ingredients: A review of ingredients evaluation strategies for aquaculture feeds. Aquac. Nutr., 13:17-34.

Hassanen G. D. I., (1991): The utilization of some unconventional protein by Nile catfish (clarias lazera). J. Egypt. Ser. Soc. Zool. Vol.(6) A:49-62, June.

Hassanen G. D. I., Sherif, M. A. and Hanafy, H. A. (1995): Utilization of some fermented waste food as a protein sources pelleted feeds for Nile Tilapia (Oreochromis niloticus) fingerlings. Proc $5^{\text {th }}$ Sci. Animal nutrition, Vol1:427-435, Ismailia, Dec.

Hassanen G. D. I., El-Azb, E. E., Allam H.Y.H and Mabrouk, M. M. (2012). Effects of partial replacement of soybean meal with seaweed meal on growth performance and immunity parameterson Nile Tilapia (Oreochromis niloticus) fingerlings. Egyptian J. Nutrition and Feeds, 15(3):649-656.

Ibrahim , A. A.(1974): chemical bacteriological and technological studies on fish protein concentrate. Ph.D. Thesis, Faculty of Agriculture, Cairo University, Egypt.

Liang, D. (2000): Effect of supplementation on the nutritive value of canola meal for broiler chickens. MSc Thesis, University of Manitoba, Winnipeg, Manitoba, Canada.

Lie, M.H., Robinson, E.H. (1994): Use of canola meal in catfish feeds. Catfish Journal; 10: 7-14.

Mazid, M. A., Tanaka, Y., Katayama, T., Rahman, M. A., Simpson, K. L., \& Chichester, C. O. (1979). Growth response of Tilapia zillii fingerlings fed isocaloric diets with variable protein levels. Aquaculture, 18(2), 115-122.

Novoa, M. A. O., F. P. Pacheco, L. O. Castillo, V. P. Flores, L. Navarro, and J. C. Samano. (1997): Cowpea (Vigna unguiculata) protein concentrate as replacement for fish meal in diets for tilapia (Oreochromis niloticus) fry. Aquaculture, 158:107-116.

Richter, N., P. Siddhuraju, and K. Becker. (2003): Evaluation of nutritional quality of moringa (Moringa oleifera Lam.) leaves as an alternative protein source for Nile tilapia (Oreochromis niloticus L.). Aquaculture 217:599-611.

Shafaeipour, A., Yavari, V., Falahatkar, B., Maremmazi, J.G., Gorjipour, E.,( 2008): Effects of canola meal on physiological and biochemical parameters in rainbow trout (Oncorhynchus mykiss). Aquacult. Nut; 14: 110-119.

Shiau, S. Y. and Kwok, C. C. (1989): Effects of cellulose, agar, carrageenan, guar gum and carboxymethylcellulose on tilapia growth. J. World Aquacult; 20:60.

Soltan, M. A., Hanafy, A. and Wafa, M. I. (2008): Effect of replacing fish meal by a mixture of different plant protein sources in Nile tilapia (Oreochromis niloticus L.) diets. Global Veterinaria, 2(4):157-164.

Steel, R. G. D., and Torrie, J. H. (1980). Principles and Procedures of Statistics. $2^{\text {nd }}$ ed. New York: McGraw-Hill.

Yiğit N.O, Seval B. K, Halit B, Arife D, Ibrahim D.(2012): Effects of canola meal on growth and digestion of rainbow trout (Oncorhynchus mykiss) fry. Turk. J. Vet. Anim. 36(5): 533-538.

Yousif, O. M., Alhamdhrami, G. A and Pessarakli, M. (1994): Evaluation of dehydrated alfalfa and salt bush (Atriplex) leaves in diets for tilapia (Oreochromis aureus L.) Aquaculture, 126: 341-347. 


\section{الملخص العربي}

الهدف من هذه الدراسة هو تكوين علائق تجريبية لأسماك البلطي الأحمر تحنوي على عناصر علفية غير التقليدية للاحلال الجزئي لبروتينات

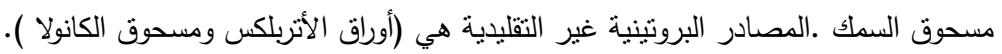

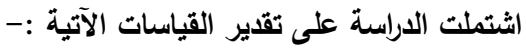

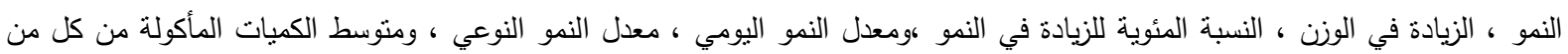

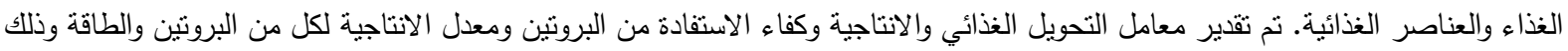

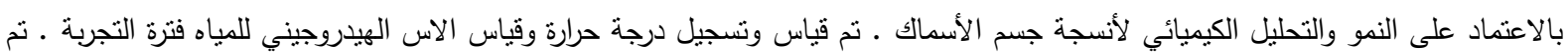

تحليل النتائج احصائيا لتحديد معنوية الفروق بين منوسطات العينات عند مستوى احتمال (0.05).

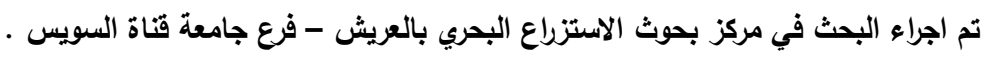

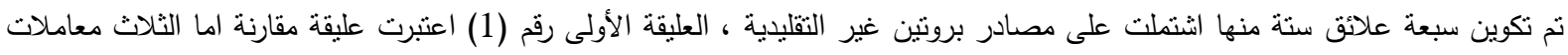
التالية (العلائق 2، 3، 4) فقد احتوت على مسحوق الكانولا بنسب 10 ، 20 ، 30 \% لتحل جزيئياً محل بروتين مسحوق السمك في عليقة

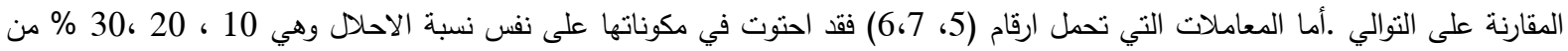
مسحوق أوراق الأتربلكس لتحل جزيئًا أيضا محل بروتينات مسحوق السمك في عليقة المقارنة .

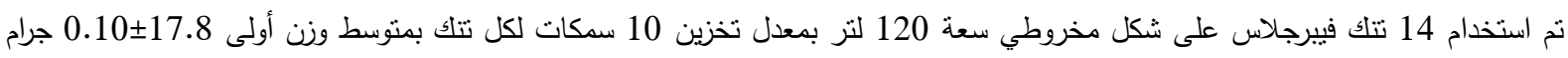

وزعت الأسماك عشوائيا وكل معاملة اثنملت على مكررتين ـ استمرت التجربة لمدة 12 اسبوع •

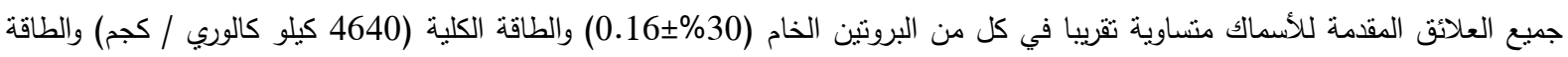

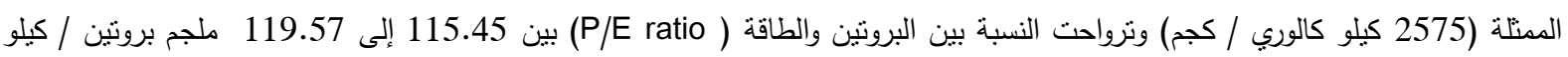
كالوري طاقة ممثلة .

\section{أهم النتائج المتحصل عليها في هذه التجرية :}

1- من غير المتوقع فقد كانت نتائج معدل النمو ومعامل التحويل الغذائي والكفاءة الغذائية والكفاء النسبية للبروتين والقيمة الاجمالية للاستفادة من البروتين والطاقة عالبة معنويا (P\0.05) في مجموعة الأسماك التي تغذت على عليقة رقم(2) التي احتوت على 10 \% مسحوق الكانولا عن مجموعة المقارنة (الكونترول - عليقة رقم 1) والتي احتوت فقط على مسحوف السمك كمصدر وحيد للبروتين • الحيواني

2- يليها العليقة المقارنة (الكونترول) من ناحبة النمو والكفاء الغذائية .

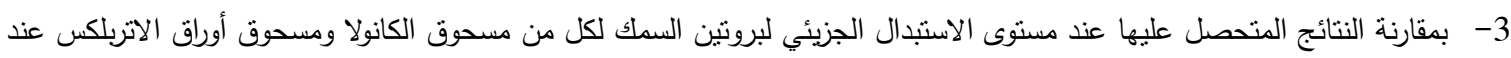
المستويات 10 ، 20 ، 30 \% اتضح أن معاملات التحويل الغذائي ، الكفاءة الغذائية ، والكفاءة النسبية للبروتين والقيمة الاجمالية للبروتين والطاقة أفضل لمجموعة الأسماك التي تتاولت الكانولا بنسبة 10 \% حتى انها تفوقت على مجموعة أسماك المقارنة

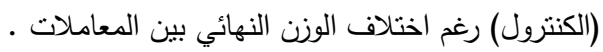
4- كانت تكلفة الكيلو جرام من الأسماك مرتفعة في عليقة (المقارنة) الكنترول والعلائق رقم 5 ، 6، 7 وهي الكي مجموعة الأتربلكس وكانت

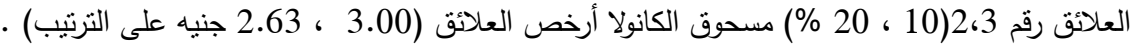
5- كانت تكلفة الكليو جرام نمو من الاسماك مرتفعة في مجموع اسماك الكنترول ومجموع أسماك الأتربلكس ورخيصة عن مجموعة الكنترول في مجموعة الاسماك التي تغذت على مسحوق الكانولا عند المستويات 10 ، 20 ،30 \% احلال جزئي لبروتينات السمك. 